\title{
Hubungan Motivasi Dengan Keaktifan Kader Posyandu Wilayah Kerja Puskesmas Gunung Tabur Tahun 2020
}

\author{
Ismail Kamba ${ }^{* 1}$, Suprihatin Ningshi ${ }^{1}$, Ratno Adrianto ${ }^{2}$, Arwan $^{3}$ \\ ${ }^{1}$ Departement of Nutrition, Faculty of Public Health, Mulawarman University, Indonesia \\ ${ }^{2}$ Departement of Health Policy Administration, Faculty of Public Health, Mulawarman \\ University, Indonesia \\ ${ }^{3}$ Departement of Health Promotion, Faculty of Public Health, Tadulako University, \\ Indonesia
}

Author's Email Correspondence (*): ismailkamba1976@gmail.com

$(+62821668874240)$

\begin{abstract}
ABSTRAK
Latar Belakang Dalam meningkatkan derajat kesehatan, pemerintah telah mencanangkan sasaran menurunkan kematian bayi menjadi 35 per 1.000 kelahiran hidup dan kematian anak balita menjadi 17 per 1.000. Untuk mencapai sasaran tersebut program pembangunan kesehatan diarahkan pada tercapainya peningkatan kemampuan masyarakat untuk hidup sehat dan dapat mengatasi masalah kesehatan melalui kegiatan posyandu. Kinerja posyandu erat kaitannya dengan keaktifan kader dalam melaksanakan tugasnya, sehingga peneliti tertarik untuk melakukan penelitian ini.Tujuan penelitian mengetahui apakah ada hubungan motivasi dengan keaktifan kader posyandu. Penelitian bersifat deskriftif analitik, rancangan cross sectional. Populasi 219 orang kader. Sampel dengan cluster random sampling 141 responden. Hasil penelitian ada hubungan motivasi dan keaktifan kader posyandu dengan nilai $\mathrm{X}^{2}{ }_{\text {hitung }}=$ $56,175>X_{\text {tabel }}^{2}=3,841, P$ value $=0,000<\alpha=0,05$, Kesimpulan terdapat hubungan signifikan motivasi dengan keaktifan kader posyandu. Saran Puskesmas dan petugas hendaknya melakukan motivasi bagi kader
\end{abstract}

Kata Kunci: Motivasi, Keaktifan, Kader Posyandu

Published by:

Tadulako University

Article history :

Address:

Received : 05112020

J1.Soekarno Hatta KM 9. Kota Palu, Sulawesi Tengah,

Indonesia.

Phone: +628114120202

Email: Preventif.fkmuntad@gmail.com 


\begin{abstract}
Background In improving health status, the government has set a target of reducing infant mortality to 35 per 1,000 live births and under-five mortality to 17 per 1,000. In order to achieve these targets, the health development program is aimed at increasing the capacity of the community to live healthily and to overcome health problems through posyandu activities. Posyandu performance is closely related to the activeness of cadres in carrying out their duties, so that researchers are interested in conducting this research. The research objective was to determine whether there was a relationship between motivation and the activeness of posyandu cadres. This research is descriptive analytic, cross sectional design. The population is 219 cadres. Sample with cluster random sampling of 141 respondents. The result of this research is that there is a relationship between motivation and activeness of posyandu cadres with a value of X2count $=56.175>X 2$ table $=3.841, P$ value $=0.000$ $<\alpha=0.05$, The conclusion is that there is a significant relationship between motivation and the activeness of posyandu cadres. Suggestions Puskesmas and officers should motivate cadres
\end{abstract}

Keywords: Motivation, Activeness, Posyandu Cadres

\title{
PENDAHULUAN
}

Pembangunan kesehatan merupakan bagian integral dari Pembangunan nasional dalam mewujudkan derajat kesehatan masyarakat yang optimal. Penguatan upaya kesehatan Dasar (primary healt Care) yang berkualitas merupakan salah satu kebijakan kesehatan dalam Pembangunan Jangka Menengah (RPJM) 2015 - 2019.(1)

Puskesmas dan Posyandu merupakan fasilitas terdepan yang menyelengggarakan pelayanan kesehatan dasar dibawah binaan Dinas Kesehatan dan merupakan kunci sukses Indonesia dalam pencapaian Program KB, Imunisasi, perbaikan gizi balita, pemantauan ibu hamil dengan faktor resiko serta pemberantasan diare (2) Pos pelayanan terpadu atau biasa disingkat Posyandu merupakan salah satu bentuk upaya kesehatan bersumber daya masyarakat (UKBM) yang diselenggarakan dari masyarakat oleh masyarakat untuk masyarakat, memperdayakan dan memberikan kemudahan kepada masyarakat guna memperoleh pelayanan kesehatan bagi ibu, bayi dan balita dengan dukungan teknis dari petugas kesehatan .(3)

Peranan kader sangat besar terhadap proses pelayanan kesehatan salah satunya tugas untuk perencanaan, pelaksanaan, evaluasi dan pengendalian serta pelaporan kegiatan di posyandu (3). Dengan melihat tugas kader tersebut dapat disimpulkan bahwa posyandu akan terlaksana dengan maksimal apabila kader posyandu aktif dalam pelaksanaan posyandu, hal

ini dikarenakan kader dapat menjadi motivator yang tepat untuk untuk membantu mewujudkan kesehatan. (3). Kader mempunyai peranan yang sangat penting pada program 
deteksi dini tumbuh kembang balita (4) Penurunan aktifitas posyandu dapat menyebabkan pemantauan gizi pada anak dan ibu hamil terabaikan (5)

Dalam beberapa tahun terakhir kinerja posyandu menurun yang disebabkan adanya droup out jumlah kader yang masih tinggi, presentasi kader aktif secara nasional adalah 69,2\% dan droup out kader sekitar 30,8\%. (6). Drop out kader sangat mempengaruhi perkembangan posyandu, drop out dikarenakan kurangnya insentif, baik uang maupun non uang seperti pelatihan, piagam, bantuan, operasional, seragam (5). Keaktifan kader sangat ditentukan oleh motivasi kader dalam melaksanakan tugasnya sebagai wujud kepedulian terhadap kesehatan masyarakat (7).

Jumlah posyandu di Indonesia tahun 2018 sebanyak 291.447 posyandu dengan jumlah kader yang aktif sebanyak 164.867 kader (36,57), jumlah kader yang tidak aktif 285.959 kader $(63,43 \%)$ di Kalimantan Timur pada tahun 2018 jumlah posyandu sebanyak 4.921 dengan jumlah kader posyandu yang aktif sebanyak $2.380(48,36 \%)$ kader dan yang tidak aktif $2.542(51,64 \%)$ (8) sedangkan jumlah posyandu di Berau tahun 2018 berjumlah 243 Posyandu posyandu dengan jumlah kader sebanyak 2.430 kader, jumlah posyandu yang aktif 134 Posyandu (55\%) dengan jumlah kader 1.340 Kader. Jumlah posyandu di wilayah Kecamatan perkotaan sebanyak 125 posyandu dan jumlah kader posyandu sebanyak 1.047 orang dengan rincian Tanjung Redeb sebanyak 24 Posyandu (keaktifan Kader 65\%), Sambaliung sebanyak 35 posyandu (keaktifan kader 48\%), Kampung Bugis 26 posyandu (keaktifan kader $92 \%$ ), Gunung Tabur 24 posyandu (keaktifan kader $24 \%$ ), Teluk Bayur 16 posyandu (keaktifan kader $29 \%$ ). Dari 5 Kecamatan tersebut keaktifan kader posyandu yang terendah adalah di Gunung Tabur yaitu dari 219 kader posyandu yang aktif hanya sebanyak 53 orang (24\%).(9).

Studi pendahuluan yang peneliti lakukan melalui wawancara terhadap 10 orang kader posyandu yang sudah tidak aktif lagi, 4 orang (40\%) mengatakan karena kurangnya motivasi untuk aktif menjadi kader posyandu, 3 orang (30\%) mengatakan karena tidak adanya penghargaan berupa insentif dari instansi terkait, 3 orang (30\%) mengatakan karena kurangnya dukungan dari petugas kesehatan dalam memberikan pembinaan. Berdasarkan uraian di atas peneliti tertarik untuk melakukan penelitian mengenai faktor-faktor yang berhubungan dengan keaktifan kader posyandu di Wilayah Kecamatan Gunung Tabur Tahun 2020. 


\section{METODE}

Jenis peneltian adalah Penelitian ini merupakan penelitian kuantitatif dengan metode deskriptif analitik yaitu melakukan analisa terhadap masing-masing variabel dalam bentuk narasi kemudian mencari hubungan sebab akibat dengan pengujian analisa statistik. Rancangan penelitian cross sectional yaitu variabel sebab dan akibat yang terjadi diukur atau dikumpulkan dalam waktu yang bersamaan (10).

Penelitian dilaksanakan sejak Agustus 2020 sampai dengan Nopember 2020. Penelitian ini dilakukan di Wilayah kerja Puskesmas Gunung Tabur. Populasi adalah keseluruhan dari variabel yang menyangkut masalah yang diteliti. Populasi dalam penelitian ini adalah seluruh kader posyandu di Wilayah Kerja Puskesmas Gunung Tabur yang berjumlah 219 orang. Sampel adalah sebagian atau sebagai wakil populasi yang akan diteliti. Pengambilan sampel menggunakan teknik cluster random sampling, rumus Slovin sebagai berikut : Cara Pengambilan Sampel dengan Cluster Random Sampling (11)

Setelah mendapatkan jumlah Sampel dan penentuan cluster, Penyebaran Kuisioner di mulai awal Agustus 2020 hingga September 2020. Jumlah kuisioner yang disebarkan berjumlah 141 kuisioner oleh peneliti. Dimana penyebaran tersebut dilakukan dengan cara memberikan angket langsung kepada Kader Posyandu.

Penyebaran kuesioner dilakukan secara tertutup dengan menggunakan skala likert 1-5. Dalam kuisioner penelitian ini terdapat bagian pernyataan - pernyataan untuk masing masing variabel, baik itu variabel dependent maupun variabel independent. Pernyataan pernyataan tersebut berhubungan dengan keaktifan kader, motivasi, sosial ekonomi dan dukungan petugas kesehatan.

\section{HASIL}

Motivasi Berdasarkan kuesioner yang telah diisi oleh responden kemudian dilakukan pengkatagorian dan disajikan dalam tabel distribusi frekuensi. 
Tabel 1.

Distribusi Frekuensi Responden Berdasarkan Motivasi Di Wilayah Kerja Puskesmas Gunung

Tabur

\begin{tabular}{cc|c}
\hline Motivasi & Frekuensi & Persentasi \\
\hline Rendah & 52 & 36.9 \\
Tinggi & 89 & 63.1 \\
\hline Total & $\mathbf{1 4 1}$ & $\mathbf{1 0 0}$ \\
\hline
\end{tabular}

Sumber : Lampiran Output SPSS

Berdasarkan data di atas mengenai motivasi dapat dilihat bahwa dari 141 responden sebanyak 89 orang $(63,1 \%)$ memiliki motivasi yang tinggi sebagai kader posyandu sedangkan 52 orang $(36,9 \%)$ memiliki motivasi yang rendah sebagai kader posyandu.

Hubungan Motivasi dengan Keaktifan Kader Posyandu Tabel silang untuk melihat tingkat keeratan hubungan antara faktor motivasi dengan keaktifan kader posyandu.

Tabel 2

Tabel Silang (Crosstab) antara Motivasi dengan Keaktifan Kader Posyandu diWilayah Kerja Puskesmas Gunung Tabur Tahun 2020

\begin{tabular}{|c|c|c|c|c|c|c|c|c|c|}
\hline \multirow{3}{*}{$\begin{array}{c}\text { Keaktifan } \\
\text { Kader }\end{array}$} & \multicolumn{4}{|c|}{ Motivasi } & \multirow{2}{*}{\multicolumn{2}{|c|}{ Total }} & \multirow{3}{*}{$\begin{array}{c}\text { X2 } \\
\text { Hitung }\end{array}$} & \multirow{3}{*}{$\begin{array}{c}\text { Spearmen } \\
\text { correlation } \\
\text { value }\end{array}$} & \multirow{3}{*}{$\begin{array}{c}\text { Exact } \\
\text { Sig. } \\
(2- \\
\text { sided })\end{array}$} \\
\hline & \multicolumn{2}{|c|}{ Rendah } & \multicolumn{2}{|c|}{ Tinggi } & & & & & \\
\hline & $\mathbf{f}$ & $\%$ & $\mathbf{f}$ & $\%$ & $\mathbf{f}$ & $\%$ & & & \\
\hline Tidak Aktif & 32 & 22.7 & 4 & 2.8 & 36 & 25.5 & & & \\
\hline Aktif & 20 & 14.2 & 85 & 60 & 105 & 74.5 & 56,175 & 0,631 & 0.000 \\
\hline Jumlah & 52 & 36.9 & 89 & 63 & 141 & 100 & & & \\
\hline
\end{tabular}

Sumber : Data Primer

Berdasarkan tabel diatas dapat dilihat dari 52 responden sebanyak 20 orang (14,2 \%) dengan motivasi yang rendah tetapi aktif sebagai kader posyandu dan 32 orang $(22,7 \% \%)$ yang tidak aktif sebagai kader posyandu, sedangkan dari 89 orang dengan motivasi yang sebanyak 85 orang $(60 \%)$ aktif sebagai kader posyandu dan 4 orang $(2,8 \%)$ tidak aktif sebagai kader posyandu.Analisis hubungan antara motivasi dengan keaktifan kader posyandu dilakukan dengan menguji hipotesa menggunakan rumus Chi Square $\left(\mathrm{X}^{2}\right)$ pada taraf signifikan $\alpha 5 \%$ dan derajat kebebasan $(\mathrm{df})=(\mathrm{a}-1)(\mathrm{b}-1)=1$. Oleh karena df-nya 
adalah 1, maka digunakan perhitungan uji Chi Square yang sudah dikoreksi. Hasil perhitungan diperoleh harga Chi Square $\left(\mathrm{X}^{2}\right)_{\text {hitung }}=56,175$, sedangkan dalam Chi Square tabel $\left(\mathrm{X}^{2}\right)_{\text {tabel }}=3,841$, jika dibandingkan dengan harga Chi Square $\left(\mathrm{X}^{2}\right)_{\text {hitung }}$ lebih besar daripada $\left(\mathrm{X}^{2}\right)_{\text {tabel }}\left(\mathrm{X}^{2}\right.$ hitung $=56,175>\mathrm{X}^{2}$ tabel $\left.=3,841\right)$. Hasil uji statistik diperoleh $\mathrm{p}=$ 0,000 lebih kecil dari pada $\alpha=0,05$ sehingga dapat disimpulkan ada hubungan yang signifikan antara faktor motivasi dengan keaktifan kader posyandu. Dari hasil analisis juga diperoleh Spearmen Correlation value $=0,631$ artinya kader posyandu yang memiliki motivasi yang kuat / tinggi sebagai kader posyandu dan mempunyai peluang atau kecenderungan untuk aktif sebagai kader posyandu sebesar 0,631 kali lebih besar dibandingkan dengan kader yang memiliki motivasi yang rendah sebagai kader posyandu.

\section{PEMBAHASAN}

\section{Motivasi dan Keaktifan Kader Posyandu}

Hasil penelitian menunjukkan terdapat hubungan yang signifikan antara motivasi dengan keaktifan kader posyandu dengan nilai $\mathrm{p}$ value $0,000<\alpha 0,05$ dan nilai X2 Hitung sebesar 56,175 lebih besar dari X2 tabel .

Hasil penelitian ini sesuai dengan teori yang dikemukakan yaitu Keaktifan kader sangat ditentukan oleh motivasi kader dalam melaksanakan tugasnya sebagai wujud kepedulian terhadap kesehatan masyarakat (7). yang menjelaskan bahwa keaktifan kader sangat ditentukan oleh motivasi kader posyandu dalam melaksanakan tugasnya sebagai wujud kepedulian terhadap kesehatan masyarakat. Dengan memiliki motivasi yang tinggi maka seorang kader akan bersemangat melaksanakan tugasnya dengan baik. Hal ini ditunjukkan dengan diperoleh spearmen Correlation value sebesar 0,631 yang artinya bahwa dengan motivasi yang kuat / tinggi sebagai kader posyandu akan memberikan peluang atau kecenderungan untuk aktif sebagai kader posyandu sebesar 0,631 kali lebih besar dibandingkan dengan kader yang memiliki motivasi yang rendah.

Hasil penelitian dapat dibuktikan dari data yang diperoleh bahwa 89 orang dengan motivasi yang tinggi sebagian besar yaitu 85 orang (60\%) aktif sebagai kader posyandu demikian pula sebaliknya dari 52 orang dengan motivasi yang rendah sebagain besar yaitu 32 orang $(22,7 \%)$ tidak aktif sebagai kader posyandu. Hal ini menunjukkan bahwa kader dengan motivasi yang tinggi mempunyai kecenderungan untuk aktif sebagai kader posyandu sebagaimana yang dikemukakan oleh Sumarsono (2012) bahwa istilah motivasi berasal dari 
kata motif yang dapat diartikan sebagai kekuatan yang terdapat dalam diri individu, yang menyebabkan individu tersebut bertindak atau berbuat. Motif tidak dapat diamati secara langsung tetapi dapat diinterpretasikan dalam tingkah lakunya berupa rangsangan, dorongan atau pembangkit tenaga munculnya suatu tingkah laku tertentu (12)(13)

Berdasarkan data dapat dilihat bahwa tidak semua kader dengan motivasi yang tinggi aktif sebagai kader demikian pula sebaliknya tidak semua kader dengan motivasi yang rendah tidak aktif sebagai kader posyandu. Dari 89 orang dengan motivasi tinggi masih ada 4 orang yang tidak aktif, hal ini dikarenakan meskipun memiliki motvasi yang tinggi tetapi karena mempunyai kesibukan bekerja maka kader tidak dapat aktif sebagai kader posyandu, sedangkan dari 52 orang dengan motivasi rendah masih ada 20 orang yang aktif, hal ini dikarenakan kader tersebut selalu mendapat dukungan dari petugas kesehatan untuk aktif sebagai kader.

Menurut pengamatan peneliti di lapangan bahwa banyaknya kader yang memiliki motivasi yang rendah dikarenakan tugas sebagai kader adalah tugas sosial yang tidak ada imbalannya sehingga sangat memerlukan tanggung jawab dan kesadaran dari dalam diri seseorang untuk aktif sebagai kader posyandu. Kurangnya penghargaan dari masyarakat terhadap tugas kader posyandu menyebabkan motivasi sebagai kader posyandu menjadi rendah, sedangkan beberapa kader mempunyai motivasi yang tinggi sebagai kader posyandu dikarenakan mereka mempunyai rasa tanggung jawab yang besar dan panggilan hati nurani untuk membantu masyarakat di sekitar tempat tinggalnya melalui kegiatan posyandu sehingga mereka merasa bermanfaat di lingkungan sekitanya. Hal inilah yang memberikan dorongan untuk bertindak aktif sebagai kader posyandu. Dengan motivasi yang tinggi maka akan mempengaruhi keaktifan sebagai kader posyandu dan melaksanakan pekerjaannya tanpa pamrih karena bertujuan untuk kegiatan sosial masyarakat sekitanya (14)(15)

\section{KESIMPULAN DAN SARAN}

Berdasarkan hasil penelitian diperoleh kesimpulan sebagai berikut ada hubungan antara motivasi dengan keaktifan kader posyandu di Wilayah Kerja Puskesmas Gunung Tabur dengan nilai $\mathrm{p}$ value 0,000 . Puskesmas dan petugas hendaknya melakukan motivasi bagi kader. 


\section{DAFTAR PUSTAKA}

1. Tenaga, M. et al. 'Rencana Pembangunan Jangka Menengah Nasional 2015-2019', 2010,"vol.021, pp. 1-266.

2. Bapenas, Penguatan Pelayanan Kesehatan Dasar di Puskesmas, 2018

3. RI, K, 'Rencana Strategis Kementerian Kesehatan Tahun 2015 - 2019'. Jakarta:2015

4. Nugroho, Haryanto Adi; Nurdiana, Dewi. Hubungan antara pengetahuan dan motivasi kader posyandu dengan keaktifan kader posyandu di desa dukuh tengah kecamatan ketanggungan kabupaten brebes. FIKkeS, 2008"Vol. 2 p.1.

5. Wirapuspita, R. 'Insentif Dan Kinerja Kader Posyandu', Kemas - Jurnal Kesehatan Masyarakat, 2013, vol. 9(1), pp. 58-65

6. Ariyana, R.'Hubungan Motivasi, insentif, dan dukungan Tokoh Masyarakat dengan kinerja kader Dalam pelaksanaan posyandu Di kelurahan Sepinggan Baru Balikpapan Tahun 2014'. Balikpapan: 2014

7. Profita, A. C. 'Beberapa Faktor Yang Berhubungan Dengan Keaktifan Kader Posyandu Di Desa Pengadegan Kabupaten Banyumas', Jurnal Administrasi Kesehatan Indonesia, 2018, vol. 6(2), p. 68

8. Kementerian Kesehatan RI. 'PROFIL Data Dan Informasi’Jakarta: 2018

9. Berau, D. 'Laporan Dinas Kesehatan Kabupaten Berau'. 2018

10. S. Notoadmodjo, Kesehatan Masyarakat Ilmu dan Seni. Jakarta: Rineka Cipta, 2011.

11. Suryana, P. D. Metodologi Penelitian Model Prakatis Penelitian Kuantitatif dan Kualitatif, Metodologi Penelitian. Edited by U. Indonesia. Uniersitas Indonesia: 2012

12. Sumarsono, Andrew, et al. Trends in aggregate use and associated expenditures of antihyperglycemic therapies among US Medicare beneficiaries between 2012 and 2017. JAMA internal medicine, 2020, 180.1: 141-144.

13. Arikunto, S. Prosedur Penelitian ; Suatu pendekatan praktik: 2010

14. Husniyawati, Y. R. and wulandari, R. D. 'Analisis Motivasi Terhadap Kinerja Kader Posyandu Berdasarkan Teori Victor Vroom', Jurnal Administrasi Kesehatan Indonesia, 2016, vol.4(2), p. 126.

15. Sumarsono, Raden Bambang. Faktor Yang Mempengaruhi Kepuasan Mahasiswa Terhadap Kualitas Layanan Laboratorium. Jurnal Manajemen Pendidikan, 2012, vol. 23, p. 411-417. 